\title{
ANALISIS YURIDIS SISTEM PENGAWASAN \\ TERHADAP KEJAHATAN PASAR MODAL
}

\author{
TITO SOFYAN
}

Fakultas Hukum Universitas Bengkulu

\begin{abstract}
Abstrak
Sistem pengawasan terutama terhadap kejahatan dan pelanggaran di pasar modal yang bermuara pada perlindungan hak-hak pemodal merupakan masalah krusial karena banyak ditemukan bukti praktek penyalahgunaan sumber-sumber daya perusahaan yang berlangsung secara ekstensif. Padahal mekanisme perdagangan di pasar modal merupakan kepercayaan, bila kepercayaan itu hilang, maka runtuhnya pasar modal akan berimbas kepada sektor lain, terutama sektor ekonomi. Meskipun Undang-Undang Nomor 8 Tahun 1995 tentang Pasar Modal (UUPM) telah mengatur ketentuanketentuan mengenai perlindungan terhadap hak-hak pemodal, namun dalam kenyataan seringkali hak-hak pemodal terabaikan karena kurangnya akses informasi terhadap sumber daya perusahaan dibanding emiten. Oleh karenanya perlu mendapatkan perlindungan hukum yang adil dan seimbang dengan emiten, melalui intervensi normanorma hukum yang sengaja diciptakan oleh negara, sebab perlindungan hukum terhadap pemodal ini tidak cukup dengan mengandalkan aspek norma-norma kebebasan berkontrak semata.
\end{abstract}

Kata kunci: sistem pengawasan, pasar modal, hak-hak pemodal

\begin{abstract}
The supervisory system especialy againts crime/violation in the capital market which led to the protection of the investor's rights is the crucial issues because it has been found many evidence of the misuse of company's resources for extensive period. Stock market is about trust, if it lose, the market will collpase and it will affect the other sector, mainly economic sector. Althoug Undang-Undang Nomor 8 Tahun 1995 tentang Pasar Modal (UUPM) it has been set up provisions for the protection of the investor's rights. But in reality the rights of the investor are oftenly neglected because of the lack of access information towards company's resources compared to that of issuers. Because of that it needs protection from law that fair and balanced, with the norm of law interference that purposefully made by the state because the legal protection that is not sufficient with just the norm of free contract.
\end{abstract}

Keywords: monitoring system, capital market, investor right 


\section{Pendahuluan}

Saham adalah tanda penyertaan modal pada Perseroan Terbatas (selanjutnya ditulis PT) sebagaimana diatur dalam UU No. 40 Tahun 2007 tentang Perseroan Terbatas (selanjutnya disebut UUPT). Pada Pasal 31 (1) UUPT disebutkan bahwa "Modal dasar PT terdiri atas seluruh nilai nominal saham".

Unsur saham merupakan ciri khas (karakteristik) dari PT. Keberadaan unsur saham tidak terlepas dalam hubungannya dengan sifat bentuk badan usaha ini sebagai asosiasi modal, yaitu suatu asosiasi yang bertujuan meng-himpun modal yang sangat besar dari sejumlah orang yang amat banyak. ${ }^{2}$ Oleh karenanya, saham sesungguhnya merupakan perwujudan dari penyertaan seseorang di dalam suatu modal perusahaan yang berbentuk PT.

Acapkali di dalam kepustakaan dibedakan antara "PT Terbuka" dan "PT Tertutup”. PT Tertutup merupakan PT yang didirikan dengan tiada maksud menjual sahamnya kepada masyarakat luas, atau tidak bertujuan menghimpun modal, ${ }^{3}$ umumnya PT jenis ini bersifat defensif dalam hal manajemennya. PT Terbuka merupakan suatu PT yang sahamnya dijual kepada masyarakat luas dalam rangka pemupukan modal untuk kepentingan investasi atau mungkin pula eksploitasi suatu PT. Pasal 1 angka 7 UUPT menyebutkan bahwa PT Terbuka adalah PT Publik ${ }^{4}$ atau PT yang melakukan penawaran umum saham melalui Pasar Modal. ${ }^{5}$

Bilamana kegiatan dunia usaha semakin berkembang, dan perusahaanperusahaan berbentuk PT bermaksud mengembangkan usahanya, maka masalah kebutuhan modal bagi usaha-usaha pengembangan tersebut merupakan hal yang sangat utama. Kebutuhan modal suatu PT, mungkin dapat diperoleh dari dalam atau pun dari luar PT. Dari dalam PT berupa pendapatan yang ditahan (penyusutan dan cadangan) serta laba yang tidak dibagikan kepada para pemilik saham dalam bentuk deviden.

\footnotetext{
${ }^{1}$ Pasal 40 ayat 1 KUHD menyebutkan bahwa "Modal PT harus dibagi dalam beberapa sero atau saham, baik atas nama, maupun blangko". Sedangkan Pasal 31 (2) UU No. 40 Tahun 2007 tentang PT, juga menyebutkan tidak tertutup kemungkinan peraturan di bidang Pasar Modal mengatur modal PT terdiri atas saham tanpa nilai nominal.

${ }^{2}$ Rudhi Prasetya, "Memerangi Penyalahgunaan PT", majalah Yuridika Surabaya, FH Unair, No 3, Tahun III, 1998, hal. 144.

${ }^{3}$ Ibid.

${ }^{4}$ Menurut Pasal 1 angka 8 Undang-Undang Nomor 40 Tahun 2007 tentang Perseroan Terbatas, yang dimaksud dengan PT Publik adalah PT yang memenuhi kriteria jumlah pemegang saham dan modal disetor sesuai dengan ketentuan peraturan perundang-undangan di bidang Pasar Modal.

5 KUHD tidak membedakan adanya bentuk PT Terbuka dan PT Tertutup, akan tetapi melihat karakteristiknya sebagai asosiasi modal seharusnya suatu PT bersifat terbuka.
} 
Sedangkan modal dari luar PT dapat berupa dana dari pemilik PT, pinjaman dari bank, pinjaman dari relasi, atau dengan menjual sebagian sahamnya. ${ }^{6}$

Alternatif sumber permodalan yang disebut terakhir di atas, yaitu modal yang didapat dengan menjual sebagian sahamnya, suatu PT dapat memperolehnya dengan dua cara yaitu melalui "penawaran terbatas" atau melalui "penawaran umum". Menurut ketentuannya, penawaran terbatas (dalam kepustakaan biasa disebut "private placement" merupakan penjualan saham secara terbatas kurang dari dua puluh orang dan atau penawarannya tidak dilakukan melalui media komunikasi massa, ${ }^{7}$ sedangkan penawaran umum (public offering) merupakan penjualan saham yang dilakukan kepada masyarakat luas melalui Pasar Modal. Untuk yang terakhir ini pada umumnya orang menyebutnya dengan istilah go-public. PT yang telah go-public artinya telah menawarkan/menerbitkan/mengemisikan sahamnya di pasar modal disebut "emiten", sedangkan pihak yang menanamkan uangnya dalam kepemilikan saham disebut "pemodal/investor". Dari beberapa alternatif sumber dan cara memperoleh permodalan di atas, yang akan menjadi fokus kajian hanya sumber permodalan yang diperoleh suatu PT dari hasil penjualan sebagian sahamnya melalui Pasar Modal.

PT Terbuka adalah perusahaan yang mendapatkan sebagian sumber permodalannya dengan melakukan penawaran umum kepada masyarakat melalui Pasar Modal. Keuntungan utama yang dapat diperoleh suatu PT yang memanfaatkan sumber permodalan dari Pasar Modal, antara lain: 1) Modal tersebut tidak terikat pada jangka waktu pemanfaatan; dan 2) Tidak mempunyai kewajiban finansial tetap, misalnya dalam bentuk pembayaran bunga dan angsuran pokok. Dengan menjual sahamnya suatu PT hanya berkewajiban memberikan deviden kepada para pemegang sahamnya dimana besar dan kecilnya tergantung pada keuntungan yang diperoleh.

Suatu Pasar Modal dapat dimanfaatkan baik oleh PT maupun anggota-anggota masyarakat yang menanamkan uangnya dalam bentuk saham (selanjutnya disebut "Pemodal"). Bagi PT, Pasar Modal dapat dimanfaatkan sebagai suatu sarana untuk menarik modal dari masyarakat yang masih tersebar dan kurang produktif, setidaktidaknya sebagai sumber permodalan alternatif bilamana sumber-sumber permodalan

\footnotetext{
6 TB. M. Hasyim, "Pasar Modal Menyongsong Pelita IV", makalah Pendidikan Latihan Perantara Perdagangan Saham (Diklat P3E), Jakarta, tanpa tahun, hal. 4.

${ }^{7}$ Periksa Keputusan Menteri Keuangan nomor 862 tahun 1987, Pasal 1 huruf 1, tentang Emisi Saham di Bursa Paralel.
} 
lain sulit diperoleh atau kurang menguntungkan. Sedangkan bagi pemodal (calon pemodal potensial) adanya Pasar Modal dapat dimanfaatkan sebagai alternatif investasi (alokasi dana) dengan kemungkinan memperoleh keuntungan PT yang dibagikan dalam bentuk deviden dan atau keuntungan dari adanya kenaikan nilai saham yang dimilikinya (capital gain).

Pengertian yang dapat ditarik dari uraian di atas menunjukan bahwa pasar modal merupakan suatu sarana yang dapat mempertemukan pihak PT yang membutuhkan tambahan modal dengan menjual sahamnya berhadapan dengan para pemilik uang (pemodal) sebagai pembelinya. Bagi PT motifnya adalah perolehan modal, sedangkan bagi para pemodal motif tersebut terletak pada keinginan untuk mendapatkan deviden dan atau capital gain.

Dalam mekanisme sistem perdagangan di pasar modal, apabila suatu saham sudah dicatatkan di bursa efek (listing), maka antara penerbit saham (emiten) dengan pemodal tidak lagi bertemu secara langsung melainkan hanya dapat dilakukan melalui perantaraan perusahaan efek sebagai perantara (broker/pialang) di bursa efek, baik sebagai perantara jual maupun perantara beli. Namun dengan adanya kesenjangan dalam komposisi kepemilikan saham dan akses informasi terhadap sumber keuangan perusahaan antara pemodal dan emiten, mengakibatkan adanya ketidakseimbangan di dalam pemenuhan hak-hak antara pemodal dan emiten. Oleh sebab itu, sistem pengawasan dengan tujuan memberikan perlindungan kepada pemodal merupakan hal yang krusial karena pada banyak negara ditemukan bukti adanya praktek penyalahgunaan (expropriation) atas sumber-sumber daya perusahaan yang berlangsung secara ekstensif. Tindakan expropriation yang dilakukan oleh pengelola perusahaan berupa manipulasi laba, penjualan asset yang tidak fair, praktek transper pricing tidak semestinya, penyertaan anggota keluarga tidak berkualitas dalam jajaran perusahaan, pembayaran gaji atau kompensasi yang berlebihan pada eksekutif ${ }^{8}$ dan lain-lainnya.

Banyak kasus pasar modal yang muncul seperti kasus saham hilang, kasus short selling, kasus laporan palsu, kasus IPO dan right issue, serta insider trading. Kasuskasus tersebut merugikan kepentingan Pemodal yang seharusnya dilindungi. Timbulnya kasus-kasus tersebut tidak terlepas dari kurang berfungsinya otoritas pasar modal yaitu Bapepam-LK (Badan Pengawas Pasar Modal-Lembaga Keuangan) yang belum

\footnotetext{
${ }^{8}$ Akhmad Syakhroza, "Best Practice Corporate Governance dalam Kontek Lokal Perbankan Indonesia, Usahawan No.06 Th.XXXII Juni 2003.
} 
melakukan penegakan hukum (law enforcement) secara konsisten, penyebabnya bisa saja karena belum ada peraturan yang mengaturnya secara secara proporsional, bisa juga karena ada pertentangan norma, atau norma yang mengaturnya kurang jelas.

Fuad Rahmany mengemukakan bahwa Undang Undang Pasar Modal perlu direvisi, karena selama ini Bapepam selalu menemui hambatan dalam melaksanakan tugasnya. Sehingga, penyelidikan yang dilakukannya tidak seluruhnya tuntas. Ada keterbatasan hukum, sehingga manipulasinya sulit untuk diusut. Dengan adanya revisi Undang Undang Pasar Modal tersebut, Bapepam akan lebih mudah mengusut kasus, seperi insider trading. Selain itu dengan revisi Undang Undang Pasar Modal, Bapepam akan dapat mengikuti MoU dengan asosiasi regulator pasar modal sedunia (International of Security Organization/IOSO). Di mana penyelidikan yang harus membuat pihaknya bertukar data dengan pihak negara lain akan menjadi lebih mudah."Kita pernah ke Hong Kong, tapi penyelidikannya buntu karena data di sana tidak bisa diberikan karena belum ikut MoU, Bapepam tidak memiliki hak untuk melihat rekening dari entitas yang dicurigai melakukan pelanggaran. Bapepam tidak punya hak untuk membuka account. Dengan revisi Undang Undang Pasar Modal akan mempermudah Bapepam dalam melaksanakan fungsi pengawasan dan penyelidikan". 9

Permasalahan yang timbul dalam praktek di mana pasar modal Indonesia sekalipun telah mempunyai perangkat hukum yaitu Undang-undang No. 8 Tahun 1995 tentang Pasar Modal dan peraturan pelaksanaannya, namun dalam kenyataanya masih belum cukup memadai, karena masih terdapat praktek-praktek yang merugikan hak-hak pemodal. Artinya bisa jadi ada masalah-masalah yang belum mendapatkan pengaturan secara proporsional, bisa juga karena ada pertentangan antara norma yang satu dengan norma yang lain baik dalam peraturan yang sama ataupun peraturan yang berbeda, namun bisa juga sudah ada pengaturannya namun perlu penjelasan lebih lanjut. Permasalahan yang dapat dirumuskan adalah apakah fungsi pengawasan di pasar modal telah efektif terutama dalam kaitannya dengan perlindungan hukum terhadap pemodal?

\section{Pembahasan}

\section{Jenis Kejahatan di Pasar Modal}

\footnotetext{
${ }^{9}$ Pernyataan Ketua Bapepam-LK, Fuad Rahmany, di Gedung BEI, Jakarta, Rabu (12/8/2009) http:/leconomy.okezone.com/read/2009/08/12/278/247492/draf-amandemen-uu-pasar-modal-masihdisempurnakan, diakses 21 Agustus 2010.
} 
Kejahatan Pasar Modal meliputi segala bentuk pelanggaran, baik terhadap ketentuan peraturan-peraturan Pasar Modal maupun peraturan lain yang berkaitan dengan kegiatan di Pasar Modal. Kejahatan Pasar Modal (capital market crime) bisa diakibatkan oleh beberapa alasan yaitu kesalahan para pelaku, kelemahan aparat yang mencakup integritas dan profesionalisme dalam menjalankan peraturan, dan pada aspek pengawasan. Lemahnya pengawasan sering terjadi dari arus tarikan para pelaku spekulan yang canggih. Sanksi terhadap kejahatan Pasar Modal Indonesia di umumnya hanyalah denda dan tidak hukuman pidana badan, sehingga asapek jeranya belum dirasakan. Oleh sebab itu, aturan untuk menangkal masalah-masalah tersebut sangat diperlukan.

Dari hal-hal tersebut dapat dilihat ketimpangan dari Pasal-Pasal yang tercantum dalam Undang-Undang Nomor 8 tahun 1995 tentang Pasar Modal, yaitu terdapat pada:

1. Pasal 35 mengenai pedoman perilaku:

Perusahaan Efek atau Penasihat Investasi dilarang :

a. menggunakan pengaruh atau mengadakan tekanan yang bertentangan dengan kepentingan nasabah;

b. mengungkapkan nama atau kegiatan nasabah, kecuali diberi instruksi secara tertulis oleh nasabah atau diwajibkan menurut peraturan perundangundangan yang berlaku;

c. mengemukakan secara tidak benar atau tidak mengemukakan fakta yang material kepada nasabah mengenai kemampuan usaha atau keadaan keuangannya;

d. merekomendasikan kepada nasabah untuk membeli atau menjual Efek tanpa memberitahukan adanya kepentingan Perusahaan Efek dan Penasihat Investasi dalam Efek tersebut; atau

e. membeli atau memiliki Efek untuk rekening Perusahaan Efek itu sendiri atau untuk rekening Pihak terafiliasi jika terdapat kelebihan permintaan beli dalam Penawaran Umum dalam hal Perusahaan Efek tersebut bertindak sebagai Penjamin Emisi Efek atau agen penjualan, kecuali pesanan Pihak yang tidak terafiliasi telah terpenuhi seluruhnya.

Kelemahan dari Pasal ini sanksinya hanya bersifat adminitratif, padahal celah ini bisa mengakibatkan berpengaruhnya harga, atau segala bentuk infor-masi maupun fakta yang dapat mempengaruhi pihak pemodal atau pihak lain yang ada hubungannya dengan Pasar Modal.

2. Dalam Pasal 90 mengatur tindakan penipuan:

"Dalam kegiatan perdagangan Saham, setiap Pihak dilarang secara langsung atau tidak langsung: 
a. Menipu atau mengelabui Pihak lain dengan menggunakan sarana dan atau cara apa pun;

b. Turut serta menipu atau mengelabui Pihak lain; dan

c. Membuat pernyataan tidak benar mengenai fakta yang material atau tidak mengungkapkan fakta yang material agar pernyataan yang dibuat tidak menyesatkan mengenai keadaan yang terjadi pada saat pernyataan dibuat dengan maksud untuk menguntungkan atau menghindarkan kerugian untuk diri sendiri atau Pihak lain atau dengan tujuan mempengaruhi Pihak lain untuk membeli atau menjual Saham".

Tetapi secara lebih detil banyak tindak pidana dan pelanggaran yang terjadi di dalam praktek yang sulit dimasukan ke dalam kelompok kejahatan tersebut seperti window dressing. Disamping itu, tindak pidana di Pasar Modal mempunyai karakteristik yang khas yaitu tindak pidana yang terjadi mengakibatkan hilangnya sejumlah saham, jumlah korban pemodal yang cukup banyak dan beragam, akhirnya dengan jumlah korban yang banyak akan meruntuhkan kepercayaan terhadap keberadaan Pasar Modal itu sendiri, dan yang paling bahaya Indonesia tidak lagi dipercaya sebagai Negara dengan tujuan investasi yang aman khususnya investasi lewat Pasar Modal.

3. Ketentuan Pasal 91 sampai dengan Pasal 93 mengatur tindakan mengenai manipulasi pasar :

Pasal 91

"Setiap Pihak dilarang melakukan tindakan, baik langsung maupun tidak langsung, dengan tujuan untuk menciptakan gambaran semu atau menyesatkan mengenai kegiatan perdagangan, keadaan pasar, atau harga Saham di Bursa Efek".

\section{Pasal 92}

"Setiap Pihak, baik sendiri-sendiri maupun bersama-sama dengan Pihak lain, dilarang melakukan 2 (dua) transaksi Saham atau lebih, baik langsung maupun tidak langsung, sehingga menyebabkan harga Saham di Bursa Efek tetap, naik, atau turun dengan tujuan mempengaruhi Pihak lain untuk membeli, menjual, atau menahan Saham".

\section{Pasal 93}

"Setiap Pihak dilarang, dengan cara apa pun, membuat pernyataan atau memberikan keterangan yang secara material tidak benar atau menyesatkan sehingga mempengaruhi harga Efek di Bursa Efek apabila pada saat pernyataan dibuat atau keterangan diberikan :

a. Pihak yang bersangkutan mengetahui atau sepatutnya mengetahui bahwa pernyataan atau keterangan tersebut secara material tidak benar atau menyesatkan; atau

b. Pihak yang bersangkutan tidak cukup berhati-hati dalam menentukan kebenaran 
material dari pernyataan atau keterangan tersebut".

Salah satu contoh pelanggaran terkait Pasal-Pasal di atas (manipulasi pasar) adalah "cornering" (goreng saham). Cornering dapat didefinisikan sebagai sebuah proses/skenario sistematis yang dilakukan oleh sebuah kelompok yang memiliki kepentingan untuk membentuk harga saham suatu perusahaan. Harga sebuah saham di bursa idealnya merupakan suatu ekuilibrium harga yang diperoleh dari permintaan/ pembelian dan penawaran/pelepasan dari saham tersebut. Mekanisme tersebut merupakan mekanisme yang alami dalam bursa berdasarkan informasi/data mengenai perusahaan atau kondisi makro ekonomi yang dipublikasikan secara transparan tanpa ada campur tangan pihak manapun. Namun tidak tertutup kemungkinan ada pihak-pihak yang memiliki kepentingan mencoba untuk membentuk harga suatu saham apakah dengan menurunkan atau menaikannya untuk memperoleh keuntungan. Di sini pelaku corner dapat menentu-kan harga saham di bursa secara semu sampai pada titik yang diinginkannya.

4. Pasal 95 dan 96 tentang insider trading (informasi orang dalam), menyebutkan :

Pasal 95

"Orang dalam dari Emiten atau Perusahaan Publik yang mempunyai informasi orang dalam dilarang melakukan pembelian atau penjualan atas Saham:

a. Emiten atau Perusahaan Publik dimaksud; atau

b. perusahaan lain yang melakukan transaksi dengan Emiten atau Perusahaan Publik yang bersangkutan”.

\section{Pasal 96}

"Orang dalam sebagaimana dimaksud dalam Pasal 95 dilarang:

a. mempengaruhi Pihak lain untuk melakukan pembelian atau penjualan atas Saham dimaksud; atau

b. memberi informasi orang dalam kepada Pihak mana pun yang patut diduga dapat menggunakan informasi dimaksud untuk melakukan pembelian atau penjualan atas Saham".

Permasalahan yang terkait dengan insider trading adalah sulitnya pembuktian telah terjadinya insider trading dalam suatu transaksi. M.S Tumanggor dalam disertasinya "Kajian Hukum atas Insider Trading di Pasar Modal Suatu Antisipasi Terhadap Pengembangan Ekonomi Indonesia" menyebutkan bahwa insider trading 
merupakan tindakan yang sulit untuk dibuktikan, bahkan di negara maju seperti Amerika Serikat. Fenomenanya adalah kejahatan insider trading sulit dibuktikan. ${ }^{10}$

Selain dari Pasal-Pasal yang ada dalam undang-undang Nomor 8 Tahun 1995 tersebut, terdapat ketimpangan lain yang berkaitan, yaitu tidak dicantumkannya ketentuan mengenai Arbitrase, padahal sebenarnya peraturan perundang-undangan yang memberikan wewenang kepada Bapepam-LK untuk menyelesaikan sengketa para pelaku Pasar Modal secara cepat, efisien, dan relatif murah sangat di perlukan. Kebutuhan penyelesaian sengketa badan arbitrase diatur dalam undang-undang yang merupakan konsekuensi dari perkembangan yang sangat dinamis mengingat kemungkinan timbulnya sengketa diantara para pelaku Pasar Modal semakin besar. Kebutuhan penyelesaian sengketa para pelaku Pasar Modal melalui arbitrase yang diatur dalam undang-undang Pasar Modal merupakan satu-satunya jalan agar terciptanya kepastian hukum dalam kegiatan Pasar Modal. Selama ini Bapepam-LK baru sebatas menyetujui peraturan-peraturan prosedural arbitrase dan memberikan rekomendasi penyelesaian sengketa yang tidak mengikat pada Badan arbitrase Pasar Modal Indonesia dan tidak mempunyai legitimasi yang kuat karena tidak dicantumkan dalam Undangundang Pasar Modal.

Dari uraian tersebut, tentang sasaran diberlakukannya Undang-Undang Pasar Modal, maka yang perlu didorong pula adalah konsistensi dalam penegakan hukum (Law Enforcement) yang diatur dalam ketentuan-ketentuanUndang-Undang Pasar Modal. ${ }^{11}$ Dengan demikian penelaahan norma-norma hukum yang menyangkut perlindungan hukum dan penegakan hukum menjadi semakin penting, mengingat lembaga Pasar Modal merupakan lembaga kepercayaan, yaitu sebagai lembaga perantara (intermediary) yang menghubungkan kepentingan pemakai dana (issuer, ultimate borrower) dan para pemilik dana (pemodal, ultimate lender).

\section{Sistem Pengawasan di Pasar Modal}

Dari berbagai studi kasus pelanggaran hukum Pasar Modal, tergambar bahwa demikian luas dan rumitnya tindak kejahatan/pelanggaran di Pasar Modal. Hal ini harus dapat diakomodir dalam pengembangan hukum Indonesia. Oleh karena itu, dalam rangka

\footnotetext{
${ }^{10}$ Tumanggor, M. S., "Kajian-Hukum-Atas-Insider-Trading-Di-Pasar-Modal-Suatu-Telaah Singkat" http://www.docstoc.com/docs/36582246/, diakses 19/01/2011.

${ }^{11}$ Ibid.
} 
penegakan hukum serta konsep pembentukan hukum nasional, kiranya pengertian hukum tidak hanya diartikan secara terbatas dan hanya terpaku kepada hukum tertulis saja. Lebih-lebih untuk mengantisipasi pelanggaran hukum di Pasar Modal, karena memang Pasar Modal Indonesia diadopsi dan lebih condong ke Amerika Serikat yang menganut sistem hukum common law (Anglo Saxon) dan berbeda dengan sistem hukum yang berlaku di Indonesia.

Apabila hanya penerapan hukum tertulis saja yang berlaku di Indonesia, maka dikhawatirkan penegakan hukum atas kejahatan dan pelanggaran hukum dibidang Pasar Modal akan sulit dilakukan, sebagai contoh sulitnya penyelesaian kasus insider trading di Pasar Modal Indonesia karena terbatasnya masalah pembuktian yang dianut dalam hukum tertulis di Indonesia. Seperti pernyataan Fuad Rahmany:

“... selama ini Bapepam selalu menemui hambatan dalam pelaksanaan tugasnya. Sehingga, penyelidikan yang dilakukannya tidak seluruhnya tuntas. Ada keterbatasan hukum, sehingga manipulasinya sulit untuk kita usut. Dengan adanya amandemen UUPM, Bapepam akan lebih mudah mengusut kasus, seperi insider trading. Dengan adanya amandemen UUPM, Bapepam akan memiliki hak untuk melihat rekening dari entitas yang dicurigai melakukan pelanggaran. Bapepam akan punya hak untuk membuka account'. ${ }^{12}$

Jika Indonesia terlalu berpegang teguh pada hukum tertulis, maka penegakan hukum Pasar Modal akan sulit, bahwa berdasarkan pengalaman, dalam kodifikasipun sering terdapat kekosongan hukum (recht vacuum = terdapat hal-hal yang belum diatur) dan di lain pihak semakin jauh pelaksanaan hukum dan keadilan disebabkan oleh terlalu tegarnya memegang undang-undang dan kodifikasi. ${ }^{13}$ Oleh karena itu tepat kiranya jika dalam penegakan hukum Pasar Modal, regulator Pasar Modal dapat menyesuaikannya dengan keadaan dan kondisi yang berkembang.

Jika dikaitkan dengan aliran pemikiran hukum, hal ini sejalan dengan pemikiran hukum dari aliran rechtbewegung yang merupakan aliran tengah di antara aliran legisme dan freie rechtbewegung. ${ }^{14}$ Bahwa menurut aliran rechtsvinding, benar bahwa hakim terikat pada undang-undang, akan tetapi tidak seketat seperti menurut pandangan legisme yang menganggap semua hukum terdapat pada undang-undang, karena hakim

\footnotetext{
${ }^{12}$ Fuad Rahmany, Ketua Bapepam-LK, di Gedung BEI, Jakarta, Rabu (12/8/2009) http:// economy.okezone.com/read/2009/08/12/278/247492/draf-amande-men-uu-pasar-modal-masih-disem purnakan.

${ }^{13}$ Yudha Bhakti Ardhiwisastra, Penafsiran dan Konstruksi Hukum, Alumni, Bandung, 2000, hal. 51.

${ }^{14}$ Soedjono Dirdjosisworo, Pengantar Ilmu Hukum, Raja Grafindo Persada, Jakarta, 2000, hal. 161.
} 
juga memiliki kebebasan. Namun kebebasan hakim tidak seperti anggapan aliran freie rechtbewegung, sehingga dalam melakukan tugasnya hakim mempunyai kebebasan yang terikat (gebonded vrijheid) atau keterikatan yang bebas (vrije gebondenheid). Oleh sebab itu maka tugas hakim disebutkan sebagai usaha melakukan rechtvinding yang artinya adalah menselaraskan undang-undang pada tuntutan zaman. ${ }^{15}$ Ketua Mahkamah Agung Bagir Manan dalam sambutannya pada pertemuan puncak pejabat tinggi negara di bidang hukum dan peradilan serta pimpinan profesi hukum (law subbmit III) tanggal 16 April 2004 di Jakarta, menyebutkan:

“...bahwa law summit I merupakan kejadian (event) dimana kesepakatan yang bersifat umum tentang perlunya rancangan tindak pembaruan hukum yang komperhensif dicapai". ${ }^{16}$

Pasar Modal dapat diklasifikasikan sebagai bidang hukum yang netral. Dalam pembentukan hukum Pasar Modal, apabila melihat undang-undang Pasar Modal, pembentukannya mendapat pengaruh dari sistem Anglo Saxon. Ini terbukti misalnya terdapat lembaga wali amanat dalam industri Pasar Modal. Oleh karena itu Pasar Modal sebagai bidang hukum yang netral, maka tidak menutup kemungkinan mendapat pengaruh dari berbagai sistem hukum. Dalam kaitan dengan hal ini Djuhaendah Hasan berpendapat, bahwa terhadap bidang hukum yang netral dapat mengambil sistem hukum dari negara lain (sistem hukum Eropa Kontinental atau Anglo Saxon) dengan tetap harus memperhatikan asas-asas dalam UUD 1945 dan pancasila. $^{17}$

Bahwa dalam teori pembentukan hukum, hakim dapat dianggap sebagai satu faktor pembentuk hukum. Hakim wajib menemukan hukum atas perkara yang ia tangani. Asas ini dianut dalam pasal 22 AB (Algemene Bepalingeen) yang walaupun produk jaman kolonial tetapi asas ini masih berlaku dalam tatanan hukum di tanah air sampai saat ini. Penafsiran dan penemuan hukum menjadi faktor bagi pengembangan hukum Pasar Modal, dalam hal ini hakim sebagai salah satu penegak hukum harus dapat menemukan dan menerapkan hukum yang berlaku bagi penyelesaian kasus pelanggaran hukum Pasar Modal yang dihadapainya, hal ini sesuai dengan ketentuan pasal 14 ayat

\footnotetext{
${ }^{15} \mathrm{Ibid}$.

${ }^{16}$ Tumanggor, Simbolon, Manumpan, "Kajian Hukum Atas Insider Trading Di Pasar Modal Suatu Antisipasi Terhadap Pengembangan Ekonomi Indonesia", Disertasi, Program Doktor Imu Hukum Pascasarjana Universitas Padjadjaran, Bandung, 2005, hal. 279.

${ }^{17}$ Djuhaedah Hasan, Lembaga Jaminan Kebendaan Bagi Tanah Dan Benda Lain Yang Melekat Pada Tanah Dalam Kensepsi Penerapan Asas Pemisahan Horizontal, Citra Aditya Bhakti, Bandung 1996, hal. 55-56.
} 
(1) UU No. 14/1970 tentang ketentuan-ketentuan pokok kekuasaan kehakiman, yang telah dirubah dengan Undang-Undang No. 35 Tahun 1999 tentang perubahan atas undang-undang No. 14 Tahun 1970 tentang Ketentuan Pokok Kekuasaan Kehakiman, terahir dengan undang-undang No. 4 Tahun 2004 tentang Kekuasaan Kehakiman pasal 28 ayat (1) hakim wajib menggali, mengikuti, dan memahami rasa keadilan yang hidup dimasyarakat.

Hakim dalam melaksanakan fungsi dan kewenangan kehakiman diberikan otonomi kebebasan. Otonomi kebebasan mencakup penafsiran peraturan perundangundangan, men-cari dan menemukan asas-asas dan dasar-dasar hukum, mencipta hukum baru apabila menghadapi kekosongan peraturan perundang-undangan, dibenarkan melakukan contra legem apabila ketentuan peraturan perundang-undangan bertentangan dengan kepentingan umum, dan memiliki otonomi yang bebas untuk mengikuti yurisprudensi. ${ }^{18}$ Dengan kewenangan yang dimiliki hakim tersebut, penemuan hukum yang dilakukan tidak sekedar menginterpretasi undang-undang atau hanya melaksanakan undang-undang saja, tetapi juga penemuan hukum karena hakim bukan hanya sebagai corong undang-undang. Melalui interpretasi yang baik, hukum akan tetap hidup dari masa ke masa dan memberikan keadilan bagi mereka yang mendambakan.

Proses pengadilan bukanlah suatu silogisme. Undang-undang merupakan premis mayor, pristiwa konkrit adalah premis minor, sedangkan putusan hakim adalah konklusi atau simpulannya. Karena itu relevan jika penerapan hukum tidak semata-mata melihat kepada hukum tertulis. Apabila hakim tidak menemukan hukum tertulis maka wajib menggali hukum tidak tertulis untuk memutus berdasarkan hukum sebagai seorang yang bijaksana dan bertanggung jawab.

Untuk mengantisipasi pelanggaran di Pasar Modal yang termasuk dalam kategori praktek curang (unfair trading) dan kejahatan pasar (market crime) diperlukan pengetahuan tentang jenis-jenis pelanggaran yang masuk kedalam kelompok tersebut. Disamping upaya penegakan hukum Pasar Modal, perlu pula kiranya untuk mendapat perhatian upaya-upaya preventif untuk menganulir kemungkinan-kemungkinan yang mengancam industri Pasar Modal di tanah air.

Pada ahirnya tujuan dari pembangunan Pasar Modal Indonesia harus sesuai dengan tujuan dan cita-cita menciptakan Pasar Modal yang teratur, wajar, dan efisien

${ }^{18}$ Retnowulan Susantio, "Perjanjian Menurut Hukum Indonesia", Varia Peradilan, Tahun V No. 56, Mei 1990. 
serta melindungi kepentingan pemodal dan masyarakat. Untuk mengimbangi karakteristik pelaku pasar modal yang aktif, kreatif, dinamis, dan agak greedy serta risk taker dibutuhkan peraturan pasar modal yang kuat. Peraturan bukan merestriksi, melainkan penyeimbang untuk menciptakan perdagangan tetap berjalan. ${ }^{19}$ Peraturan pasar modal di Indonesia sudah bagus, karena telah setara dengan peraturan di berbagai negara di dunia. Hanya saja dalam kondisi krisis, menurut dia, implementasi sejumlah pilar pasar modal sangat dibutuhkan. Di antaranya, otoritas tertata rapi, regulasi yang sudah siap, enforcement melalui pembinaaan, pengawasan, dan pelaksanaan. ${ }^{20}$

\section{Lembaga Pengawas Pasar Modal}

Di Indonesia lembaga pengawas Pasar Modal adalah Badan Pengawas Pasar Modal (Bapepam-LK). Fungsi yang harus dilaksanakan Bapapem sebagai lembaga pengawas pada dasarnya ada enam kondisi umum yang mutlak harus dimiliki.

Pertama, sebagai institusi pengawas Bapepam memerlukan sifat independensi yang cukup tinggi. Artinya, Bapepam harus memiliki landasan hukum yang kuat, peraturan yang lengkap, jelas dan posisi kelembagaan yang cukup tinggi, serta tidak semata-mata berada pada satu unit Departemen yang malah harus mereka awasi. Bahkan kalau memungkinkan harus diangkat atau dinominasi oleh DPR bersama-sama Presiden seperti halnya the Securities and Exchange Commission (SEC) di AS. ${ }^{21}$

Kedua, Bapepam harus diisi atau dipimpin oleh orang-orang yang memenuhi kualifikasi yang dikehendaki pasar. Orang-orang yang dikehendaki pasar pada dasarnya merupakan orang-orang yang mengerti, ahli dan berpengalaman di bidangnya, serta memiliki integritas berdasarkan penilaian pasar.

\footnotetext{
${ }^{19}$ Parluhutan Situmorang, Investor Daily Indonesia, Oktober-November 2011, hal. 14.

${ }^{20}$ Ibid.

21 Saat ini dasar berdirinya Bapepam adalah Kepres. No.53 Tahun 1990 diikuti dengan Kep.Men.Keu.No.1548/KMK.013/1990 jo. Kep.Men.Keu.No.1199/ KMK.010/1991. Dalam ketentuan ini Bapepam diubah fungsinya dari Badan Pelaksana Pasar Modal menjadi Badan Pengawas Pasar Modal, artinya, Bapepam tidak lagi menjadi penyelenggara pasar, tetapi hanya memfokuskan peranannya di bidang pengawasan. Ini kemudian ditegaskan lagi dalam UU No. 8 tahun 1995 tentang Pasar Modal. Dalam pasal 3 ayat (1) disebutkan pembinaan, pengaturan dan pengawasan sehari-hari kegiatan Pasar Modal dilakukan oleh Bapepam. Berikutnya dalam pasal 4 ditegaskan peran Bapepam itu bertujuan mewujudkan terciptanya kegiatan Pasar Modal yang teratur, wajar, dan efisien serta melindungi kepentingan pemodal dan masyarakat. Tugas dan fungsinya sama dengan SEC di Amerika Serikat. Bapepam adalah organ pemerintah di bawah pengawasan Departemen Keuangan. Karena itu baik Ketua,Wakil Ketua serta pejabat-pejabat lainnya yang melaksanakan tugas di Bapepam adalah Pegawai Negeri. Hal ini sama dengan keanggotaan SEC di Korea Selatan.
} 
Ketiga, Bapepam harus diisi oleh orang-orang yang memiliki keberanian (courage) untuk mengambil keputusan, sehingga institusi yang dipimpin dan pasar yang diawasi tidak berada pada suasana kebingungan dan kevakuman. Bagi pelaku bisnis, lambat dalam pengambilan keputusan berarti risiko dan cost Lebih-lebih dalam suasana krisis seperti sekarang ini.

Keempat, semakin kompleksnya aktifitas Pasar Modal dan semakin banyaknya keterlibatan pemain internasional mengharuskan Bapepam memiliki pemahaman dan penguasaan terhadap aspek pasar keuangan internasional termasuk kerjasama dengan international regulators dan international agencies terkait. ${ }^{22}$

Kelima, sebagai regulator, Bapepam harus mampu membuat aturan main yang dibutuhkan pasar dan mengacu kepada standar internasional. Di samping itu, harus dihindari agar tidak terjadi situasi di mana setiap aturan yang dibuat tidak dilaksanakan. Artinya bahwa implementasi dari setiap aturan main sama pentingnya dengan kelahiran aturannya sendiri, kendati pun hal ini memerlukan waktu dan tidak mudah.

Keenam, harus disadari bahwa pasar yang efisien memerlukan adanya kepastian hukum. Ini merupakan syarat penting sebelum keputusan investasi dibuat. Kepastian hukum di sini termasuk, sistem peradilan yang cepat, adil dan efisien termasuk pengadilan niaga, konsistensi dalam penerapan aturan main, termasuk kemampuan untuk menerbitkan interpretative releases (penjelasan resmi) oleh Bapepam terhadap masalah yang menjadi pertanyaan masyarakat. ${ }^{23}$

Perlu disadari bahwa Pasar Modal sensitif terhadap suatu kejadian baik itu peristiwa politik, ekonomi maupun sosial lainnya. Oleh karena itu tidak berlebihan kalau dikatakan bahwa Pasar Modal, merupakan pasar yang dilandasi kepercayaan (trust). Masalah kepercayaan ini erat kaitannya dengan persoalan integritas. Selama ini kita mendengar bahwa Bapepam telah mengembangkan sistem monitoring terhadap pelaku pasar melalui pengembangan catatan (records) yang akurat yaitu Daftar Orang Tercela (DOT). Sistem ini seharusnya diimplementasikan secara terbuka, fair dan tidak

\footnotetext{
${ }^{22}$ Kita (Bapepam) pernah ke Hong Kong, tapi penyelidikannya buntu karena data di sana tidak bisa diberikan karena belum ikut MoU, dengan perubahan UUPM, Bapepam akan dapat mengikuti MoU dengan asosiasi regulator Pasar Modal sedunia (Internastional of Security Organization/IOSO). Di mana penyelidikan yang harus membuat pihaknya bertukar data dengan pihak negara lain akan menjadi lebih mudah. Pernyataan Fuad Rahmany, Ketua Bapepam-LK, di Gedung BEI, Jakarta, Rabu (12/8/2009), http://economy.okezone.com/read/2009/08/12/278/247492/draf-amandemen-uu-pasar-modal-masihdisempurnakan.

${ }^{23}$ I Putu Gede Ary Suta, Menuju Pasar Modal Modern, Yayasan Sad Satria Bhakti, Jakarta, 2000.
} 
diskriminatif. Sekali penerap-annya menyimpang, tidak fair, tidak terbuka dan diskriminatif akan menjadi preseden buruk yang dapat melahirkan lunturnya kepercayaan masyarakat. Di samping itu perlu diketahui bahwa seharusnya konsep DOT ini juga dapat diupayakan implementasinya terhadap regulator, atau pejabatpejabat lainnya. Sehingga siapapun yang akan menjadi pengawas Pasar Modal harus terbebas dari penilaian sebagai orang tercela (masuk DOT). Dengan begitu pengawas Pasar Modal merupakan cerminan dari orang-orang yang disegani dan diterima oleh pasar bukan orang-orang tercela di pasar yang mereka awasi. ${ }^{24}$

Era baru pengawasan di bidang Pasar Modal berubah dengan disahkannya UU No. 21 Tahun 2011 tentang Otoritas Jasa Keuangan (selanjutnya disebut UU OJK), pada tanggal 22 Nopember 2011. Ketentuan Pasal 55 ayat (1) UU OJK menyebutkan bahwa sejak tanggal 31 Desember 2012, fungsi, tugas, dan wewenang pengaturan dan pengawasan kegiatan jasa keuangan di sektor Pasar Modal, Perasuransian, Dana Pensiun, Lembaga Pembiayaan, dan Lembaga Jasa Keuangan Lainnya beralih dari Menteri Keuangan dan Badan Pengawas Pasar Modal dan Lembaga Keuangan (Bapepam-LK) kepada OJK. Sedangkan untuk fungsi, tugas, dan wewenang pengaturan dan pengawasan kegiatan jasa keuangan di sektor Perbankan beralih dari Bank Indonesia kepada OJK pada tanggal 31 Desember 2013 (Pasal 55 ayat (2) UU OJK). Realisasi dari Pasal ini mundur 1 bulan yakni dimulai sejak tanggal 1 Januari 2013 untuk pengaturan dan pengawasan Pasar Modal dan Lembaga keuangan nonbank, sebagaimana pernyataan Ketua Dewan Komisioner OJK :

“... Mulai 1 Januari 2013, pengaturan dan pengawasan Pasar Modal dan Lembaga Keuangan Non-Bank dilakukan oleh Otoritas Jasa Keuangan (OJK). Selama ini, kedua lembaga tersebut berada di bawah pengawasan Badan Pengawas Pasar Modal dan Lembaga Keuangan (Bapepam-LK). Tahun depan, OJK akan menjalankan tugas untuk mengawasi industri perbankan yang selama ini masih dijalankan oleh Bank Indonesia."25

Otoritas Jasa Keuangan (OJK) adalah suatu lembaga independen yang terdiri dari sembilan anggota dewan komisaris yang sifatnya kolektif kolegial dimana terdapat dua anggota unsur perwakilan ex-officio dari Pemerintah yakni, Perwakilan Bank Indonesia dan Kementerian Keuangan, yang lainnya adalah sektoral.

\footnotetext{
${ }^{24} \mathrm{Ibid}$

${ }^{25}$ KOMPAS.com, Rabu, 2 Januari 2013, 04:17 WIB, dan pernyataan Muliaman D Hadad, Ketua Dewan Komisioner Otoritas Jasa Keuangan, Kompas, Jumat, 4 Januari 2013, hal. 20.
} 
Pasal 70 UUOJK menyebutkan bahwa pada saat Undang-Undang UUOJK mulai berlaku, Undang- Undang Nomor 8 Tahun 1995 tentang Pasar Modal (Lembaran Negara Republik Indonesia Tahun 1995 Nomor 64, Tambahan Lembaran Negara Republik Indonesia Nomor 3608) dan peraturan pelaksanaannya, serta peraturan perundang-undangan lannya di sektor keuangan dinyatakan tetap berlaku sepanjang tidak bertentangan dan belum diganti berdasarkan Undang-Undang ini.

Dengan ketentuan tersebut di atas, maka kewenangan yang dimiliki OJK tidak hanya meliputi kewenangan yang secara tegas disebutkan dalam UU OJK, melainkan juga berbagai kewenangan terkait pengaturan dan pengawasan jasa keuangan yang diatur dalam Undang-Undang Nomor 8 Tahun 1995 tentang Pasar Modal. Kewenangan yang dimiliki OJK ini merupakan kewenangan yang diambil alih dari kewenangan yang sebelumnya dimiliki oleh Bapepam-LK. Pembaruan pengaturan dalam pengawasan dan pengaturan kegiatan jasa keuangan ini tidak hanya dimaksudkan untuk menggantikan kedudukan Bapepam-LK dalam melakukan pengawasan terhadap kegiatan pasar modal, namun juga memberikan kewenangan terhadap OJK yang sifatnya lintas sektoral di sektor jasa keuangan.

Selain itu ditambahkan pula bahwa lembaga ini melibatkan keterwakilan unsur-unsur dari kedua otoritas tersebut secara Ex-officio. Keberadaan Ex-officio ini dimaksudkan dalam rangka koor dinasi, kerja sama, dan harmonisasi kebijakan di bidang fiskal, moneter, dan sektor jasa keuangan. Keberadaan Ex-officio juga diperlukan guna memastikan terpeliharanya kepentingan nasional dalam rangka persaingan global dan kesepakatan internasional, kebutuhan koordinasi, dan pertukaran informasi dalam rangka menjaga dan memelihara stabilitas sistem keuangan. ${ }^{26}$

Selama masa transisi tugas pengawasan pasar modal berjalan seperti biasa yaitu dipegang oleh Bapepam, setelah masa transisi penuh maka semua kewenangan akan pindah kepada OJK. Berdasarkan Pasal 68 menyatakan:

“... Sejak beralihnya fungsi, tugas dan wewenang sebagaimana di maksud dalam Pasal 55, pemeriksaan dan/ atau penyidikan yang sedang dilakukan oleh Bank Indonesia, Kementerian Keuangan dan Badan Pengawas Pasar Modal dan Lembaga Keuangan, penyelesaiannya dilanjutkan ke OJK”.

Sehingga tugas dan kewenangan yang dimiliki Bapepam semua pindah ke OJK, termasuk penyelesaian kasus di pasar modal yang terus berjalan dari masa

${ }^{26}$ Vicky Ho dkk, "Fungsi Otoritas Jasa Keuangan Dalam Penanganan Kejahatan Manipulasi Pasar Di Pasar Modal”, Analisis, Juni 2014, Vol. 3 No. 1: 37-44, hal 41. 
transisi sampai transisi selesai. Maka OJK lah yang akan menyelesaikan kasus tersebut. Bapepam sendiri nanti tidak berada di bawah Menteri Keuangan. Tapi sepenuhnya tugas Bapepam akan pindah ke pada OJK. OJK bakal kebanjiran kasus pasar modal setelah Bapepam melebur ke OJK. Karena Bapepam belum bisa menyelesaikan seluruh kasus yang ditangani. ${ }^{27}$

Bapepam menyatakan tidak ada peraturan pasar modal yang akan berubah pasca beralihnya badan pengawasan pasar modal ke OJK maupun selama masa transisi. Peraturan secara substansi tetap sama perubahan hanya di mana lembaga yang mengeluarkan aturan saja. Kalau sebelumnya Bapepam nanti OJK. ${ }^{28}$

\section{Kesimpulan}

Pemodal merupakan salah satu unsur dalam aktivitas Pasar Modal yang sangat penting. Dari sisi hukum perjanjian, pada dasarnya hubungan antara pemodal dan emiten adalah hubungan yang bersifat kontraktual dimana kedudukan kedua belah pihak seimbang. Namun dengan adanya kesenjangan dalam komposisi kepemilikan saham dan akses informasi terhadap sumber keuangan perusahaan antara pemodal dan emiten (pengelola), mengakibatkan adanya ketidakseimbangan di dalam pemenuhan hak-hak antara pemodal dan emiten. Tidak efektifnya pengawasan sering terjadi dari arus tarikan para pelaku spekulan yang canggih. Sanksi terhadap kejahatan Pasar Modal Indonesia umumnya hanyalah denda dan tidak hukuman pidana badan, sehingga aspek jeranya belum dirasakan.

Di Indonesia lembaga pengawas Pasar Modal adalah Badan Pengawas Pasar Modal (Bapepam-LK), dimana mulai 1 Januari 2013 beralih ke Otoritas Jasa Keuangan (OJK) berdasarkan UU No. 21 Tahun 2011 tentang Otoritas Jasa Keuangan. Namun demikian, Undang- Undang Nomor 8 Tahun 1995 tentang Pasar Modal tetap berlaku sepanjang tidak bertentangan dan belum diganti. Kewenangan yang dimiliki OJK merupakan kewenangan yang diambil alih dari kewenangan yang sebelumnya dimiliki oleh Bapepam-LK. Fungsi yang harus dilaksanakan lembaga pengawas pada dasarnya ada enam kondisi umum yang mutlak harus dimiliki: independen; dipimpin oleh orang-

\footnotetext{
${ }^{27}$ Susi Muliyanti dkk, “Analisis Yuridis Kedudukan Badan Pengawas Pasar Modal (Bapepam) Setelah Berlakunya Undang-Undang No. 21 Tahun 2011 Tentang Otoritas Jasa Keuangan”, USU Law Journal, Vol.II-No.2 (Nov-2013), hal. 86.

${ }^{28}$ Ibid.
} 
orang yang memenuhi kualifikasi yang dikehendaki pasar; memiliki keberanian (courage) untuk mengambil keputusan; memiliki pemahaman dan penguasaan terhadap aspek pasar keuangan internasional; sebagai regulator sekaligus pengawas, OJK harus mampu membuat aturan main yang dibutuhkan pasar dan mengacu kepada standar internasional; dan adanya kepastian hukum agar pasar efisien.

\section{Daftar Pustaka}

Akhmad Syakhroza, "Best Practice Corporate Governance dalam Kontek Lokal Perbankan Indonesia", Usahawan No.06 Th.XXXII Juni 2003.

Djuhaedah Hasan, Lembaga Jaminan Kebendaan Bagi Tanah dan Benda Lain yang Melekat pada Tanah dalam Kensepsi Penerapan Asas Pemisahan Horizontal, Citra Aditya Bhakti, Bandung 1996.

Http://economy.okezone.com/read/2009/08/12/278/247492/draf-amandemen-uu-pasarmodal-masih-disempurnakan, diakses 21 Agustus 2010.

Http://ekonomi.kompasiana.com/bisnis/2012/11/08/awal-2013-tampil-lembaga-superotoritas-jasa-keuangan-ojk-506792.html, diakses 10 Februari 2012.

I Putu Gede Ary Suta, Menuju Pasar Modal Modern, Yayasan Sad Satria Bhakti, Jakarta, 2000.

Kompas, Jumat, 4 Januari 2013.

Kompas.com, Rabu, 2 Januari 2013.

Parluhutan Situmorang, Investor Daily Indonesia, Oktober-November 2011.

Retnowulan Susantio, "Perjanjian Menurut Hukum Indonesia", Varia Peradilan, Tahun V No. 56, Mei 1990.

Rudhi Prasetya, "Memerangi Penyalahgunaan PT", majalah Yuridika, Fakultas hukum Universitas Airlangga, Surabaya, nomor 3, tahun III, 1998.

Soedjono Dirdjosisworo, Pengantar Ilmu Hukum, Raja Grafindo Persada, Jakarta, 2000.

Susi Muliyanti dkk, "Analisis Yuridis Kedudukan Badan Pengawas Pasar Modal (Bapepam) Setelah Berlakunya Undang-Undang No. 21 Tahun 2011 tentang Otoritas Jasa Keuangan”, USU Law Journal, Vol.II-No. 2 Nov-2013.

TB. M. Hasyim, "Pasar Modal Menyongsong Pelita IV", makalah Peserta Pendidikan Latihan Perantara Perdagangan Saham (Diklat P3E)", Jakarta, t.th.

Tumanggor, M. S., "Kajian Hukum atas Insider Trading di Pasar Modal: Suatu Telaah Singkat" http://www.docstoc.com/docs/36582246/.diakses 19 Januari 2011.

Tumanggor, Simbolon, Manumpan, "Kajian Hukum atas Insider Trading di Pasar Modal Suatu Antisipasi Terhadap Pengembangan Ekonomi Indonesia", Disertasi Program Doktor Imu Hukum Pascasarjana Universitas Padjadjaran, Bandung, 2005. 
Vicky Ho dkk, "Fungsi Otoritas Jasa Keuangan Dalam Penanganan Kejahatan Manipulasi Pasar di Pasar Modal”, Jurnal Analisis, Vol.3 No.1 : 37-44, Juni 2014.

Yudha Bhakti Ardhiwisastra, Penafsiran dan Konstruksi Hukum, Alumni, Bandung, 2000.

\section{Perundang-undangan}

UU No. 40 Tahun 2007 tentang Perseroan Terbatas.

UU No. 8 Tahun 1995 tentang Pasar Modal.

Keputusan Menteri Keuangan Nomor 862 Tahun 1987 tentang Emisi Saham di Bursa Paralel.

Kitab Undang-Undang Hukum Dagang 